\title{
Variability and Sources of Ambient Volatile Organic Compounds Based on Online Measurements in a Suburban Region of Nanjing, Eastern China
}

\author{
Rongrong Wu ${ }^{1}$, Yu Zhao ${ }^{1,2 *}$, Jie Zhang ${ }^{2,3}$, Lei Zhang ${ }^{1}$ \\ ${ }^{1}$ State Key Laboratory of Pollution Control \& Resource Reuse and School of the Environment, Nanjing University, \\ Nanjing, Jiangsu 210023, China \\ ${ }^{2}$ Collaborative Innovation Center of Atmospheric Environment and Equipment Technology, CICAEET, Nanjing, Jiangsu \\ 210044, China \\ ${ }^{3}$ Jiangsu Provincial Academy of Environmental Science, Nanjing, Jiangsu 210036, China
}

\begin{abstract}
Volatile organic compounds (VOCs) are the key precursors of ozone $\left(\mathrm{O}_{3}\right)$ and secondary organic aerosol (SOA) formation. To identify the variation in VOCs emission sources, simultaneous VOCs measurements were conducted for one year at a suburban site (Xianlin Campus of Nanjing University (NJU)) in Nanjing, a highly polluted city of the Yangtze River Delta (YRD) region in China. The annual average concentration of VOCs at NJU was observed to be $18.95 \pm 14.95 \mathrm{ppbv}$, with alkanes, alkenes and aromatics contributing $67.5 \%, 13.6 \%$ and $18.9 \%$, respectively, of the total mass concentration. The ratios for $i$-pentane/ $n$-pentane and $m, p$-xylene/ethylbenzene showed that the ambient VOCs at NJU were affected by fuel evaporation and long-distance transport. A positive matrix factorization (PMF) model was applied for source apportionment of the VOCs, and seven factors were identified. Vehicle exhaust, evaporation, natural gas (NG) and aged air masses, combustion and synthetic industries, solvents and painting, petrochemical plants and mixed industrial sources were estimated to contribute $23.5 \%, 16.3 \%, 15.9 \%, 14.6 \%, 13.2 \%, 10.8 \%$ and $5.6 \%$, respectively. The contribution from traffic emissions (i.e., vehicle exhaust) exceeded that suggested by a local emission inventory (9.7\%). The concentration-weighted trajectory (CWT) model revealed that the highly polluted air masses arriving at NJU originated in the industrial areas of northeastern Nanjing and the YRD. The contributions from petrochemical plants, solvents and painting, and aged air masses were found to be increased during $\mathrm{O}_{3}$ and $\mathrm{PM}_{2.5}$ pollution days in suburban areas, indicating the importance of reducing industrial emissions and jointly controlling VOCs on a regional scale.
\end{abstract}

Keywords: VOCs; Source apportionment; Positive matrix factorization; Pollution episodes.

\section{INTRODUCTION}

As the key precursors of ozone $\left(\mathrm{O}_{3}\right)$ and secondary organic aerosol (SOA) formation, volatile organic compounds (VOCs) lead to severe air pollution (Huang et al., 2014; Lyu et al., 2016; Wu and Xie, 2017) and, thereby, cause damage to human health (WHO, 2003). Although biogenic emissions dominate at the global scale (Guenther et al., 2006), anthropogenic sources are more influential at the regional and urban scales (Zhao et al., 2017). Due to the uneven distribution of human activities and the associated emission sources, there is significant variability in the spatial and temporal distribution of individual VOCs, influencing the secondary pollutant formation and causing difficulties in

\footnotetext{
${ }^{*}$ Corresponding author.

Tel.: 86-25-89680650

E-mail address: yuzhao@nju.edu.cn
}

creating strategies for the control of precursors (Latif et al., 2012; Jiang et al., 2018). Therefore, a better understanding of VOCs sources is important for regional and urban air quality improvement.

With rapid economic development in China, air pollution with high levels of ozone $\left(\mathrm{O}_{3}\right)$ and fine particulates $\left(\mathrm{PM}_{2.5}\right)$ has been widely reported in many regions (He et al., 2017). The emissions of anthropogenic VOCs, the key precursors of ambient $\mathrm{O}_{3}$ and $\mathrm{PM}_{2.5}$, have doubled during the past two decades (Zhao et al., 2017). Previous studies have been conducted to analyze the characteristics and identify the sources of ambient VOCs using receptor models on megalopolis clusters such as the Beijing-Tianjin-Hebei (BTH) region (Li et al., 2015; Wang et al., 2015), the Yangtze River Delta (YRD) region (Mo et al., 2017; Zhu et al., 2018) and the Pearl River Delta (PRD) region (Zhang et al., 2015; Mo et al., 2018; Ou et al., 2018) in China. For example, An et al. (2014) used principal component analysis/absolute principal component scores (PCA/APCS) to investigate VOCs sources at an industrial site in Nanjing. However, the variation in the 
VOCs sources might be different for suburban areas. In the PRD region, for example, gridded measurements of VOCs were conducted, and spatial discrepancies in VOCs sources were observed (Mo et al., 2018; Ou et al., 2018). A larger contribution of industrial processes was found in the industrial area, while a larger contribution of gasoline-related sources was found in suburban zones. To comprehensively evaluate the influence of atmospheric VOCs on air quality and to further identify the sources, further measurements of ambient VOCs at other functional areas are still needed.

A few studies have shown various sources of VOCs during pollution days. Sun et al. (2016) calculated the SOA formation potentials of VOCs during the winter haze period in Beijing and found that emissions from vehicles, chemical industries and solvents were the main causes of elevated VOCs. Wu et al. (2016) suggested that extremely high levels of VOCs during the haze event could be primarily attributed to vehicular emissions, biomass burning and regional transport and were aggravated by unfavorable meteorological conditions. However, most studies of pollution events have focused on particulate matter (PM) and those focusing on $\mathrm{O}_{3}$ are still limited. In most developed regions of China, air pollution with high levels of $\mathrm{O}_{3}$ and $\mathrm{PM}$ has become one of the most severe environmental pollution issues (Huang et al., 2014; $\mathrm{Xu}$ et al., 2018), and $\mathrm{O}_{3}$ has gradually replaced PM to be the major pollutant in summer (MEP, 2018). Therefore, studies on the characteristics and source variations of VOCs on $\mathrm{O}_{3}$ and PM pollution days are urgently needed to help provide scientific support, enabling the government to formulate effective air pollution control measures.

Nanjing is a typical developed city in the YRD region of eastern China with intensive chemical industries. The annual emissions of anthropogenic VOCs were estimated to increase from 148 to $253 \mathrm{Gg}$ during the period of 2005-2014 (Zhao et al., 2017). Under prevailing northeastern and southeastern winds, Nanjing is located downwind of the entire YRD region and is influenced by the long-distance transport of pollutants. Ding et al. (2013) and Chen et al. (2019) reported high levels of $\mathrm{O}_{3}$ and $\mathrm{PM}_{2.5}$ concentrations with near-surface observation data in this region. In this study, we conducted simultaneous online measurements of ambient VOCs at suburban areas for a full year. The diurnal and seasonal variations in VOCs and diagnostic ratios were evaluated to understand the temporal differences of VOCs levels. The sources of VOCs were identified, and their contributions to ambient concentrations were quantified through the positive matrix factorization (PMF) method. Both the PMF method and the PCA/APCS models do not need prior information about the number of VOCs sources and the VOCs emission source profiles. However, PMF model was chosen over PCA/APCS models because it could identify VOCs sources by limiting all the elements in the factor profiles and the factor loading matrix to positive values (Yuan et al., 2009), and could deal appropriately with data that are below the method detection limit (MDL; Hu et al., 2018). Finally, the source contribution during $\mathrm{O}_{3}$ and $\mathrm{PM}_{2.5}$ pollution days was investigated to improve policy making regarding air quality improvement.

\section{METHODS}

\section{Site Description}

VOCs measurements were conducted at the Xianlin Campus of Nanjing University (NJU; $32.12^{\circ} \mathrm{N}, 118.96^{\circ} \mathrm{E}$ ) in Nanjing, as shown in Fig. 1. The instruments at NJU were set on the roof of a building, $20 \mathrm{~m}$ above the ground. NJU is a suburban site, located in northeastern Nanjing, approximately $20 \mathrm{~km}$ from downtown (Li et al., 2016; Chen et al., 2017). Under the prevailing southeastern winds in the summer monsoon season, NJU has often been affected by urban plumes from the megacity Shanghai and the Suzhou-WuxiChangzhou city cluster (Zhao et al., 2019).

Due to the technical problems with the instruments at NJU, other species in the atmosphere, including $\mathrm{O}_{3}, \mathrm{PM}_{2.5}$, carbon monoxide $(\mathrm{CO})$ and nitrogen dioxide $\left(\mathrm{NO}_{2}\right)$, were measured and reported at a state-operated air quality observation site in Xianlin (XL; $32.11^{\circ} \mathrm{N}, 118.91^{\circ} \mathrm{E}$; https://data.epmap.org). The XL site is $4.5 \mathrm{~km}$ west of the NJU site, as shown in Fig. 1. Our previous study demonstrated that the relatively close distances did not lead to a large bias in air quality (Chen et al., 2017); thus, we can assume that the data from the XL site is representative of the atmospheric conditions around NJU.

\section{Sampling and Analysis}

The concentrations of 55 VOCs species were measured by an online $\mathrm{O}_{3}$ Precursor Analyzer System (PerkinElmer (PE), Waltham, MA, USA) from March 2016 to February 2017 at NJU. At a flow rate of $15 \mathrm{~mL} \mathrm{~min}{ }^{-1}$, air samples were collected for 40 min every hour and then passed through a Nafion dryer to remove water vapor. The dried samples were first concentrated in a trap maintained at $-30^{\circ} \mathrm{C}$ and later desorbed when the trap was heated to $350^{\circ} \mathrm{C}$ at a rate of $40^{\circ} \mathrm{C} \mathrm{s}^{-1}$ in the thermal desorbers (TD 300; PE). Finally, the compounds were transferred into a gas chromatograph system (GC 580; PE) by an ultra-pure (99.999\%) helium carrier.

The gas chromatograph system was operated with two columns and two flame ionization detectors (FIDs). 55 compounds, including alkanes, alkenes and aromatic hydrocarbons, were classified into $\mathrm{C}_{2}-\mathrm{C}_{6}$ and $\mathrm{C}_{6}-\mathrm{C}_{12}$ categories. The former was separated in the PLOT column $\left(\mathrm{Al}_{2} \mathrm{O}_{3} / \mathrm{Na}_{2} \mathrm{SO}_{4}, 50 \mathrm{~m} \times 0.32 \mathrm{~mm} \times 5 \mu \mathrm{m}\right)$ and then identified by the first FID. The latter was separated in the BP-1 column $\left(\mathrm{Al}_{2} \mathrm{O}_{3} / \mathrm{Na}_{2} \mathrm{SO}_{4}, 50 \mathrm{~m} \times 0.22 \mathrm{~mm} \times 1 \mu \mathrm{m}\right)$ and then identified by the second FID. The temperature program for the GC oven was increased from $46^{\circ} \mathrm{C}$ to $170^{\circ} \mathrm{C}$ at a rate of $5^{\circ} \mathrm{C} \mathrm{min}^{-1}$, then increased to $200^{\circ} \mathrm{C}$ at a rate of $15^{\circ} \mathrm{C} \mathrm{min}$, and was finally maintained at $200^{\circ} \mathrm{C}$ for $9 \mathrm{~min}$. The sample residence time for measuring VOCs with GC-FID was $50 \mathrm{~min}$, and a chromatogram with identified retention times is presented in Fig. S1.

The analytical uncertainty on species was evaluated from the observed reproducibility and linearity of standard gas. Running for ten times, the relative standard deviations of concentration-response (peak area) were $0.34-2.78 \%$ for 55 species. The calibration curves were obtained by running the five diluted standards and the correlation coefficients for the calibration curves were $0.9929-0.9999$ for 55 species. The 


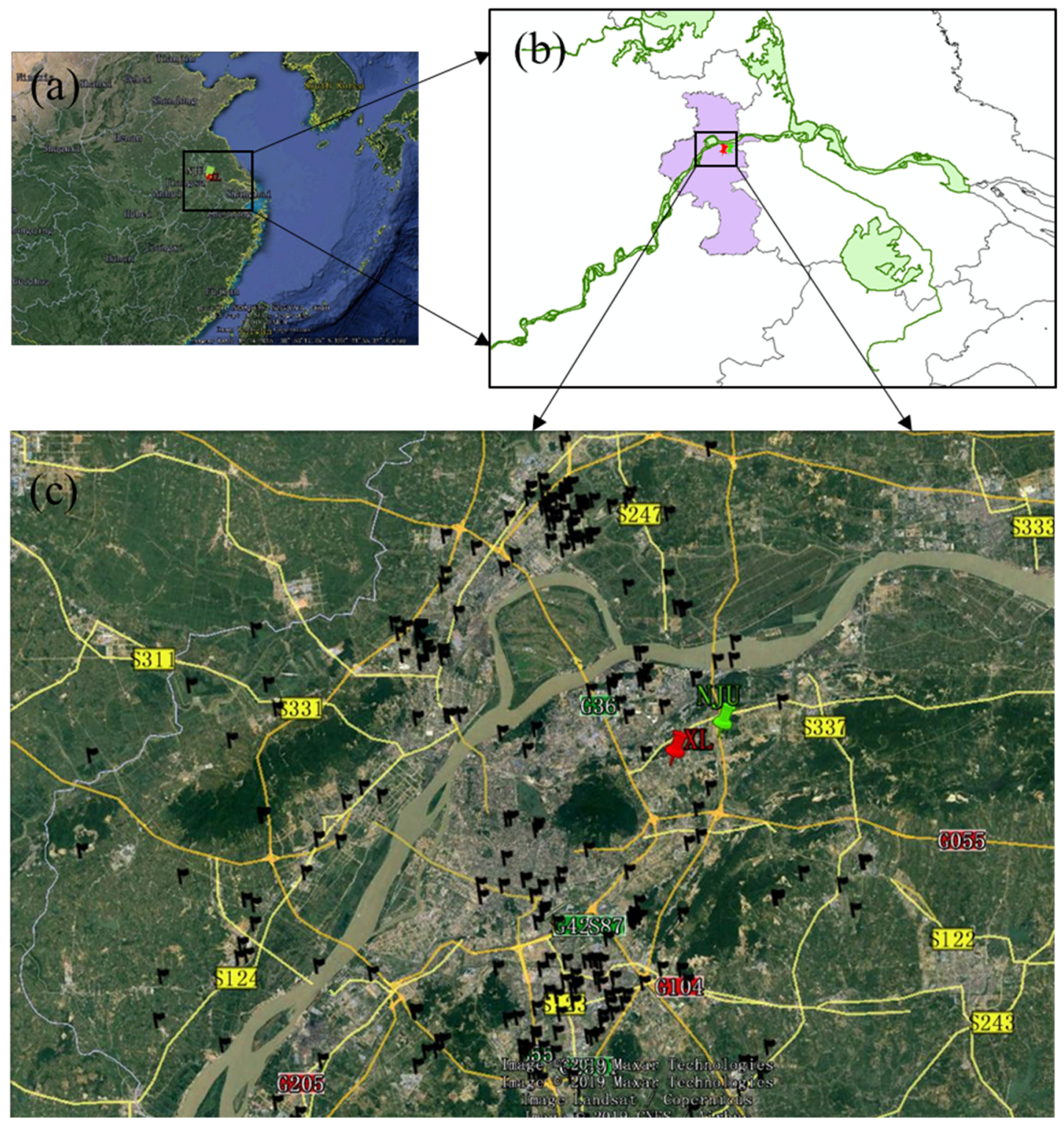

Fig. 1. The locations of the NJU and XL sites in Nanjing. The green and red marks represent NJU and XL site, respectively. The black flags are main factories with annual VOCs emission over $1 \mathrm{t}$. The (b) green lines and (c) yellow lines are river path and road, respectively.

analytical system was checked daily with a one-point calibration. The standard gases from the Photochemical Assessment Monitoring Stations (PAMS, Linde) were used at 00:00 every day. If the response was within $\pm 10 \%$ of the initial calibration curve, the measurements were expected to be reliable. Fig. S1 illustrates the retention times of species in a sample and a standard gas, which were consistent with each other. The method detection limit (MDL) of a certain VOC was calculated according to Eq. (1) (Xia et al., 2014):

$M D L=\frac{3 \times N \times W}{H}$

where $N$ is the noise $(\mathrm{mV}), W$ is the concentration of the calibration sample (ppbv) and $H$ is the response $(\mathrm{mV})$. The MDLs of individual VOCs are listed in Table S1.
The methods recommended in the National Ambient Air Quality Standards in China (NAAQS-CN) were used for the measurement of other species at the XL site. $\mathrm{O}_{3}$ and $\mathrm{PM}_{2.5}$ were monitored with a Model $49 i \mathrm{O}_{3}$ Analyzer and a Thermo Scientific TEOM 1405D, respectively, and the concentrations of $\mathrm{NO}_{2}$ and $\mathrm{CO}$ were measured with Thermo Scientific TEOM $42 i$ and $48 i$, respectively. All the samples were collected at hourly intervals. Meteorological data, including solar radiation, wind speed, air temperature, precipitation, relative humidity and surface air pressure, were recorded at the automatic weather station at NJU.

\section{Positive Matrix Factorization (PMF)}

The EPA PMF 5.0 program (U.S. EPA, 2014) was used to identify VOCs sources and to quantify their contributions. For a certain number of factors, PMF analysis can obtain the 
factor contributions and factor profiles by minimizing the object function $Q$ (Paatero and Tapper, 1994; Paatero, 1997):

$$
Q=\sum_{i=1}^{n} \sum_{j=1}^{m}\left(\frac{x_{i j}-\sum_{k=1}^{p} g_{i k} f_{k j}}{u_{i j}}\right)^{2}
$$

where $i, j$ and $k$ represent the VOCs compound, emission source and sampling, respectively; $x$ represents the concentration; $g$ represents the profile matrix; $f$ represents the score matrix; and $u$ represents the residual factor.

Both the concentration data file and the corresponding uncertainty data file are required as inputs of the PMF. For the concentrations, ND (not detected) data and data lower than the MDL were replaced by a value of half the MDL (Hopke et al., 2000; Yuan et al., 2012). Only species in which at least $70 \%$ of measurements were above the MDL were chosen for PMF analysis. Although the procedure in PMF model would eliminate "bad variables," it categorizes a species as "bad" only if all the samples are missing (U.S. EPA, 2014; Ou et al., 2015). The uncertainties (Unc) of those concentration values (Conc) that were below or equal to the MDL were calculated using Eq. (3) (Polissar et al., 1998; Reff et al., 2007):

$$
U n c=\sqrt{(\text { Error Fraction } \times \text { Conc })^{2}+(0.5 \times M D L)^{2}}
$$

If the concentrations were higher than the MDL, Eq. (4) was used (Polissar et al., 1998; Reff et al., 2007):

$$
U n c=\frac{5}{6} \times M D L
$$

The Error Fraction in Eq. (3) was considered as measurement uncertainty and was set as $10 \%$ for all species.
PMF ran from four to ten factors to obtain meaningful solutions. The determination of PMF factor number was shown in Section S1.

\section{Concentration-weighted Trajectory (CWT)}

The CWT model, reflecting the concentration levels of the trajectories, was used to distinguish the pollution levels of different potential regions and to identify the potential source regions of atmospheric VOCs. The 48-h backward trajectories with 1-h intervals (from 01:00 to 23:00 local time (LT)) were simulated for each day from March 2016 to February 2017 with TrajStat (Wang et al., 2009). The details were shown in Section S2.

\section{RESULTS AND DISCUSSION}

\section{Concentrations and Temporal Variations in Ambient VOCs}

The annual mean concentrations, standard deviations (SD) and MDLs of all 55 VOCs species at NJU are summarized in Table S1. The mean concentration of the total VOCs was $18.9 \mathrm{ppbv}$, and alkanes, alkenes and aromatics contributed $67.5 \%, 13.6 \%$ and $18.9 \%$ of the total mass concentration, respectively. The top 10 abundant species were propane, ethane, $n$-butane, $i$-pentane, ethene, toluene, $i$-butane, benzene, $n$-pentane and propene, and their concentrations collectively accounted for $76.7 \%$ of the total VOCs concentrations. The top 10 abundant species and their average concentrations were compared with the results of previous studies conducted in the YRD region, as shown in Table 1. The top 10 abundant species at the industrial site in Nanjing (An et al., 2014) were similar to those in this study, with slight differences in their ranking, emphasizing the differences of dominant VOCs sources at two areas. Furthermore, the average concentrations of VOCs components observed in this work were generally lower than those in An et al. (2014), with the differences ranging from 0.16 to $4.47 \mathrm{ppbv}$. The measurement site reported in An et al. (2014) was $25 \mathrm{~km}$ from NJU and was located

\begin{tabular}{|c|c|c|c|c|c|c|c|c|c|}
\hline \multicolumn{2}{|c|}{ Nanjing $^{\mathrm{a}}$} & \multicolumn{2}{|c|}{ Nanjing $^{b}$} & \multicolumn{2}{|c|}{$\mathrm{Ningbo}^{\mathrm{c}}$} & \multicolumn{2}{|c|}{ Shanghai $^{\mathrm{d}}$} & \multicolumn{2}{|c|}{ The mid-lower Yangtze Rivere } \\
\hline \multicolumn{2}{|c|}{ Suburban } & \multicolumn{2}{|c|}{ Industrial } & \multicolumn{2}{|c|}{ Suburban } & \multicolumn{2}{|c|}{ Urban } & \multicolumn{2}{|c|}{ Waterway } \\
\hline Propane & 3.29 & Ethane & 6.97 & Ethane & 2.45 & Propane & 4.81 & Ethane & 7.44 \\
\hline Ethane & 2.89 & Ethene & 5.68 & Propane & 2.37 & Toluene & 4.70 & Propane & 5.66 \\
\hline$n$-Butane & 1.53 & Propane & 3.29 & Ethene & 1.92 & $i$-Pentane & 2.29 & Ethene & 5.24 \\
\hline$i$-Pentane & 1.26 & Benzene & 3.14 & $i$-Butane & 1.72 & $n$-Butane & 2.03 & $n$-Butane & 4.36 \\
\hline Ethene & 1.21 & Propene & 2.45 & $n$-Butane & 1.26 & Benzene & 1.81 & Propene & 3.78 \\
\hline Toluene & 1.07 & Toluene & 2.10 & Propene & 1.05 & $i$-Butane & 1.43 & $i$-Butane & 1.72 \\
\hline$i$-Butane & 0.98 & $n$-Butane & 1.69 & Toluene & 0.90 & $m, p$-Xylene & 1.40 & $i$-Pentane & 1.50 \\
\hline Benzene & 0.82 & 1-Butene & 1.61 & $i$-Pentane & 0.75 & Ethylbenzene & 1.23 & Toluene & 1.09 \\
\hline$n$-Pentane & 0.78 & $i$-Butane & 1.51 & Benzene & 0.45 & Propene & 0.84 & $n$-Pentane & 1.04 \\
\hline Propene & 0.70 & Ethylbenzene & 1.19 & $m, p$-Xylene & 0.40 & - & - & - & - \\
\hline
\end{tabular}

Table 1. Comparison of the top ten abundant species and their average concentrations measured in different cities in the YRD region (unit: ppbv).

a This study. Sampling period: from March 2016 to February 2017.

${ }^{\mathrm{b}}$ An et al. (2014). Sampling period: from March 2011 to February 2012.

${ }^{\mathrm{c}}$ Mo et al. (2017). Sampling period: December 2012, April 2013, July 2013, and October 2013.

${ }^{\mathrm{d}}$ Cai et al. (2010). Sampling period: from January 2007 to March 2010.

${ }^{\mathrm{e}}$ Zhu et al. (2018). Sampling period: from November 2015 to December 2015. 
approximately $3 \mathrm{~km}$ from a large-scale industrial chemical park; as such, the strong emissions from those sources would have a greater influence on the ambient VOCs levels. The annual average concentration of species in suburban Nanjing was similar to that in Ningbo (Mo et al., 2017) but lower than that in Shanghai (Cai et al., 2010). This result was reasonable, since the VOCs emissions were usually higher in Shanghai than in Nanjing and Ningbo (Huang et al., 2011). The most significant species in this study differed from those in urban Shanghai. Nanjing had high abundances of $\mathrm{C}_{2}-\mathrm{C}_{4}$ alkanes, while Shanghai was rich in aromatics. The differences in dominant species probably highlighted the various sources of VOCs. In addition, the concentrations of VOCs species along the mid-lower Yangtze River were higher than those in this study, which might be attributed to the influence of ship emission along the waterway. The TVOCs and chemical groups between this study and previous studies observed at other metropolitan areas in the world were also compared, as shown in Table S2. The annual average concentration of TVOCs in this study was similar to that in suburban Yokohama (Tiwari et al., 2010) but lower than Guangzhou (Zou et al., 2015). It was lower than that in urban areas in other cities such as Beijing (Wang et al., 2010), Wuhan (Hui et al., 2018), Chung-Ming (Huang et al., 2019),
Paris (Baudic et al., 2016), Mexico City (Garzon et al., 2015) and Houston (Leuchner and Rappengluck, 2010).

The seasonal variations of TVOCs, chemical groups and selected VOCs species observed at NJU are shown in Fig. 2. These species, including the top 10 abundant species, ethylbenzene and $m, p$-xylene, were typical tracers for various VOCs sources. For example, $\mathrm{C}_{2}-\mathrm{C}_{5}$ alkanes could be emitted from vehicle exhaust or fuel evaporation, while aromatics were tracers of solvent usage. Similar seasonal patterns were found for most VOCs species and chemical groups, i.e., the highest concentrations were observed in winter, and the lowest concentrations were observed in summer. The mean concentrations of those VOCs species in winter were $28-158 \%$ higher than those in summer. The higher concentrations in winter resulted from diminished photochemical activities under suppressed diffusion conditions and lower temperature, while the lower concentrations in summer could result from intensive photochemical reactions in the atmosphere. The concentrations of some species, such as butane isomers and pentane isomers, were observed to increase slightly in summer. These species are tracers of engine exhaust or fuel evaporation. George et al. (2015) found that vehicle emissions measured in warm ambient temperatures were lower than those in cold temperatures.
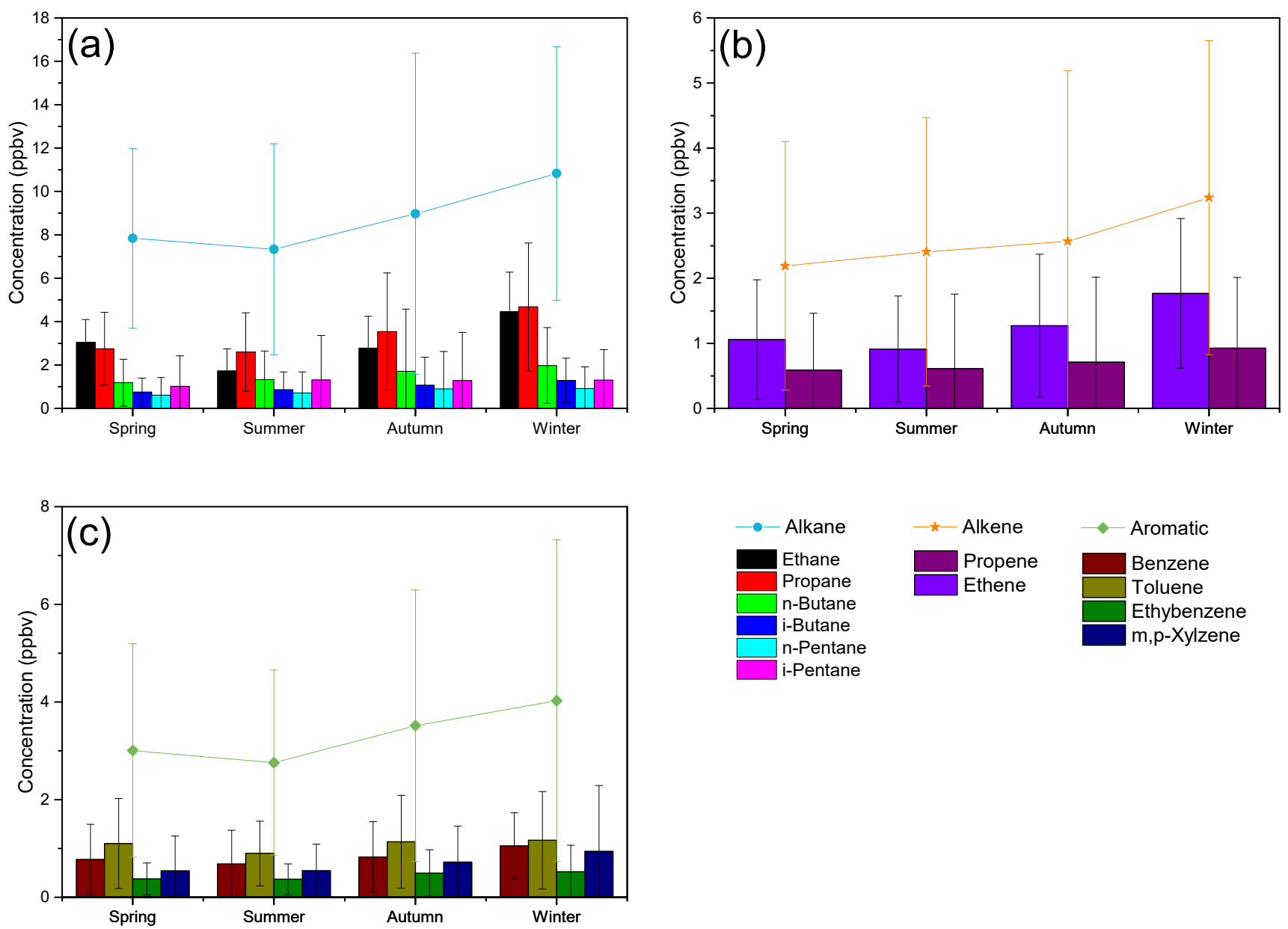

Fig. 2. Seasonal variations in (a) alkanes, (b) alkenes and (c) aromatics during the sampling period. The error bars represent \pm 1 standard deviation from the total averages. 
Therefore, the results emphasized the volatilization of VOCs from evaporation in suburban areas. For chemical groups, the concentration of alkenes was observed to slightly increase in summer, suggesting the presence of additional sources, e.g., biogenic sources with substantial isoprene emissions (Mochizuki et al., 2014).

Fig. 3 shows the diurnal variations of TVOCs, chemical groups and selected VOCs species. The VOCs exhibited similar trends, with concentrations accumulating at night and decreasing during the day. Despite the continuous release of VOCs, the VOCs levels were reduced because of the oxidation of $\mathrm{VOCs}$ by $\mathrm{OH}$ radicals during the day and the increased dispersion and dilution of pollutants due to the elevation of the planetary boundary layer (PBL).

\section{The Concentration Ratios of Selected Species by Season}

The chemical compositions of VOCs in the emission sources were assumed to be relatively constant throughout the day, and it was assumed that the abundance of the more reactive species in the atmosphere would decrease during the day due to photochemical reactions. Therefore, the VOCs ratios for ambient concentrations have often been used to explore the emission sources of VOCs and the photochemical age of air masses (Yan et al., 2017; Zheng et al., 2018). In this study, the ratios of $i$-pentane to $n$-pentane $(\mathrm{I} / \mathrm{N})$ and of $m, p$-xylene to ethylbenzene $(\mathrm{X} / \mathrm{E})$ were selected. The correlations of the two pairs of species at the seasonal level are illustrated in Fig. 4.
The pentane isomers had approximately the same rate of reaction with $\mathrm{OH}$ radicals (Atkinson, 1986), and their ratio was a reliable indicator for the identification of emission sources, since these compounds were equally affected by photochemical processing. A higher ratio of $\mathrm{I} / \mathrm{N}$ was reported in vehicle emissions (2.2-3.8) and fuel evaporation (1.8-4.6) than in NG evaporation (0.82-0.89) (Gilman et al., 2013; McGaughey et al., 2004; Watson et al., 2001). In this study, the squared correlation coefficient values $\left(\mathrm{R}^{2}\right)$ of the linear regression fitting for the pentane isomer ratios were large (0.65-0.91), indicating a similar source for the two species. The ratios of $\mathrm{I} / \mathrm{N}$ ranged from 1.2-1.9 according to season at NJU, with the maximum values found in summer. Since the effects of photochemical processing on pentane isomers were equal, the higher $\mathrm{I} / \mathrm{N}$ ratio in summer probably indicated that the larger influence of fuel evaporation (not vehicle emissions since the emission strength of vehicles would be stronger in cold weather). The ratios at NJU suggested that the pentanes were more likely from the mixed sources of $\mathrm{NG}$ and fuel evaporation. This assumption was proved by the correlation analysis between pentane isomers and other VOCs species. As shown in Table 2, the pentane isomers at the NJU site displayed stronger correlations $\left(0.72<\mathrm{R}^{2}<0.85\right)$ with butane isomers (typical tracers of gasoline) and weaker correlations $\left(0.11<\mathrm{R}^{2}<0.41\right)$ with alkenes and aromatic hydrocarbons (associated with vehicle exhaust). This result suggested that gasoline evaporation contributed a greater concentration of pentane isomers in suburban areas.
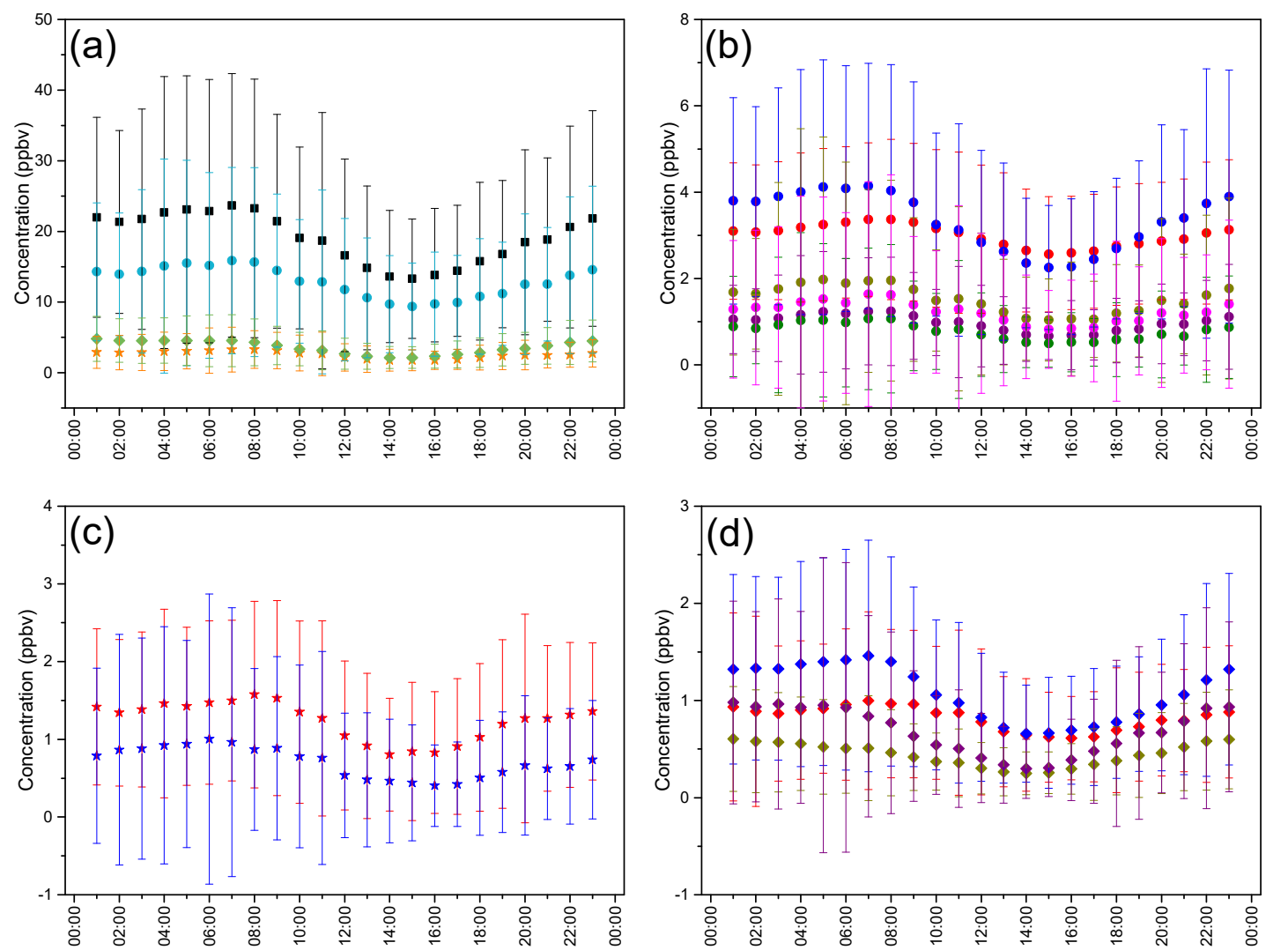

- TVOCs

Alkane

Alkene

Aromatic

- Ethane

- Propane

- n-Butane

- i-Butane

- n-Pentane

- i-Pentane

* Ethene

$\star$ Propene

- Benzene

- Toluene

- Ethyibenzene

- m,p-Xylzene

Fig. 3. Daily variations in (a) TVOCs and chemical groups, and (c-d) twelve species during the sampling period. The error bars represent \pm 1 standard deviation from the total averages. 


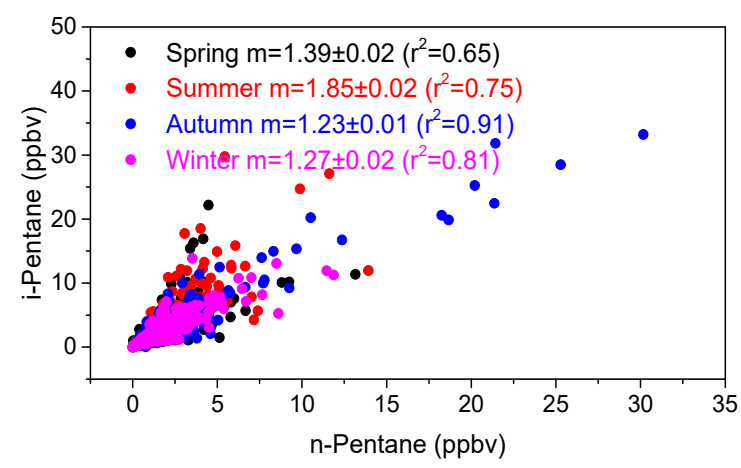

(a)

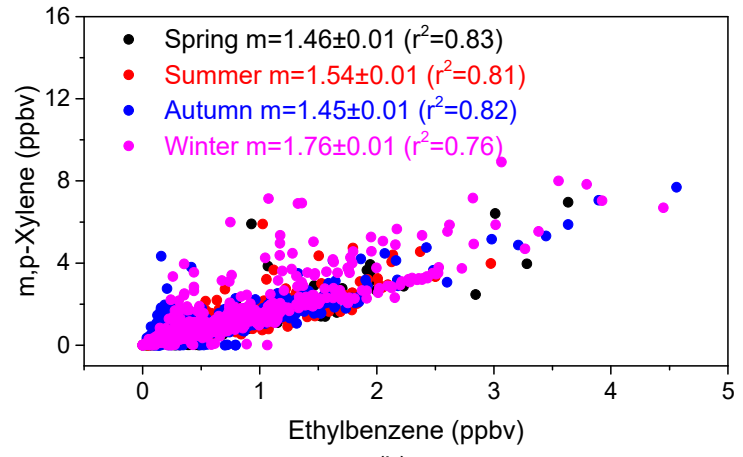

(b)

Fig. 4. Correlations between (a) $i$-pentane and $n$-pentane and between (b) $m$,p-xylene and ethylbenzene. Linear regression fitting is applied to symbols in each season and the corresponding slopes $(\mathrm{m}=$ slope \pm standard error $)$ and correlation coefficients $\left(\mathrm{R}^{2}\right)$ are shown in the plots.

Table 2. Correlations $\left(\mathrm{R}^{2}\right)$ between species at the NJU site.

\begin{tabular}{lll}
\hline & $n$-Pentane & $i$-Pentane \\
\hline Ethane & 0.23 & 0.19 \\
Propane & 0.41 & 0.32 \\
$n$-Butane & 0.85 & 0.72 \\
$i$-Butane & 0.74 & 0.75 \\
Ethene & 0.22 & 0.17 \\
Propene & 0.31 & 0.26 \\
Benzene & 0.26 & 0.20 \\
Toluene & 0.14 & 0.11 \\
\hline
\end{tabular}

The ratio of $m, p$-xylene to ethylbenzene (X/E) was a typical indicator of photochemical age. The atmospheric lifetime of ethylbenzene (1.6 days) was longer than that of $m, p$-xylene (11.8-19.4 h; Monod et al., 2001), and the ratio of X/E decreased as the VOCs air masses underwent photochemical reactions in the atmosphere. An X/E ratio below 3 was identified as "aged" due to long-range transport, whereas a ratio above 3 was considered a local emission (Kuntasal et al., 2013; Yurdakul et al., 2018). As shown in Fig. 4(b), the ratios at NJU were estimated to be 1.5-1.8, showing that the air masses that affected the observation points exhibited a certain degree of aging. The highest ratios occurred in winter as expected due to weak photochemical activities. The diurnal variations of $\mathrm{X} / \mathrm{E}$ are shown in Fig. S2. It was observed to continuously decline by $35 \%$ from $07: 00$ to 15:00 LT, indicating the increased photochemical removal processes during the day.

\section{Source Apportionments and Geographic Origins of VOCs}

Source contributions to VOCs were calculated using the PMF model for hourly samples throughout the entire year. Only 24 species including 13 alkanes, 3 alkenes and 8 aromatics were used in the PMF model, since $70 \%$ of their concentrations were above the MDL. According to the variations of $\mathrm{Q} / \mathrm{Q} \exp$ and factor profiles, introduced in Section S1, a seven-factor solution was finally chosen. The $\mathrm{R}^{2}$ value between the calculated and measured total VOCs concentrations at $\mathrm{NJU}$ was 0.98 , showing that the PMF solutions could well explain the variance in the total measured concentrations. Fig. 5 illustrates seven source profiles and their contributions to the annual ambient VOCs extracted from the PMF, and the seasonal and diurnal variations of the factor contributions are provided in Fig. 6 and Fig. S3, respectively.

Factor 1 consisted mainly of toluene, ethylbenzene, $m, p$ xylene, $o$-xylene, $m$-ethyltoluene, 1,2,4-trimethylbenzene, and methylcyclopentane, and was consistent with the source profiles of solvent usage measured in Wang et al. (2014). Although aromatics were also reported to be emitted from traffic emissions (Borbon et al., 2001; Buzcu et al., 2006), Factor 1 was regarded as solvent and painting since it had higher contributions in summer (15\%) than winter (11\%) (Fig. 6). Previous studies have demonstrated that emission strength of vehicular exhaust would be higher at cold temperature while that of solvent usage would be higher at warm temperature (George et al., 2015; Song et al., 2019).

The main tracer species of Factor 2 were methylcyclopentane, benzene, cyclohexane, $n$-heptane and toluene. These species have been reported to be emitted from petroleum refineries (Bari and Kindzierski, 2018). The average contributions of this factor were rather stable in both day and night. The seasonal variation in this factor displayed higher contributions in spring-summer (14\%) than in autumnwinter $(6-12 \%)$, consistent with the emission strength of petrochemical plants. The petrochemical plants would contribute more VOCs at higher temperatures (Song et al., 2019). Therefore, Factor 2 at NJU was expected to represent petrochemical plants.

Large fractions of ethane (59\%) were found in Factor 3. Ethane is the main species of natural gas (NG; Xiao et al., 2008; McCarthy et al., 2013), and it has a long atmospheric lifetime (Zheng et al., 2018). As shown in Fig. S3(c), the contributions of Factor 3 were larger in the afternoon, when the ambient levels of oxidation products were usually high. Therefore, Factor 3 was likely a mixture of NG and aged air masses. Besides, the seasonally averaged contributions of this factor significantly varied, from $12 \%$ in summer to $21-$ $28 \%$ in winter-spring. It further proved that concentrations of this factor likely resulted from aged air masses, since weaker photochemical reactions and atmospheric dynamics in winter would lead to greater accumulation of VOCs, and thus, to higher source contributions. 


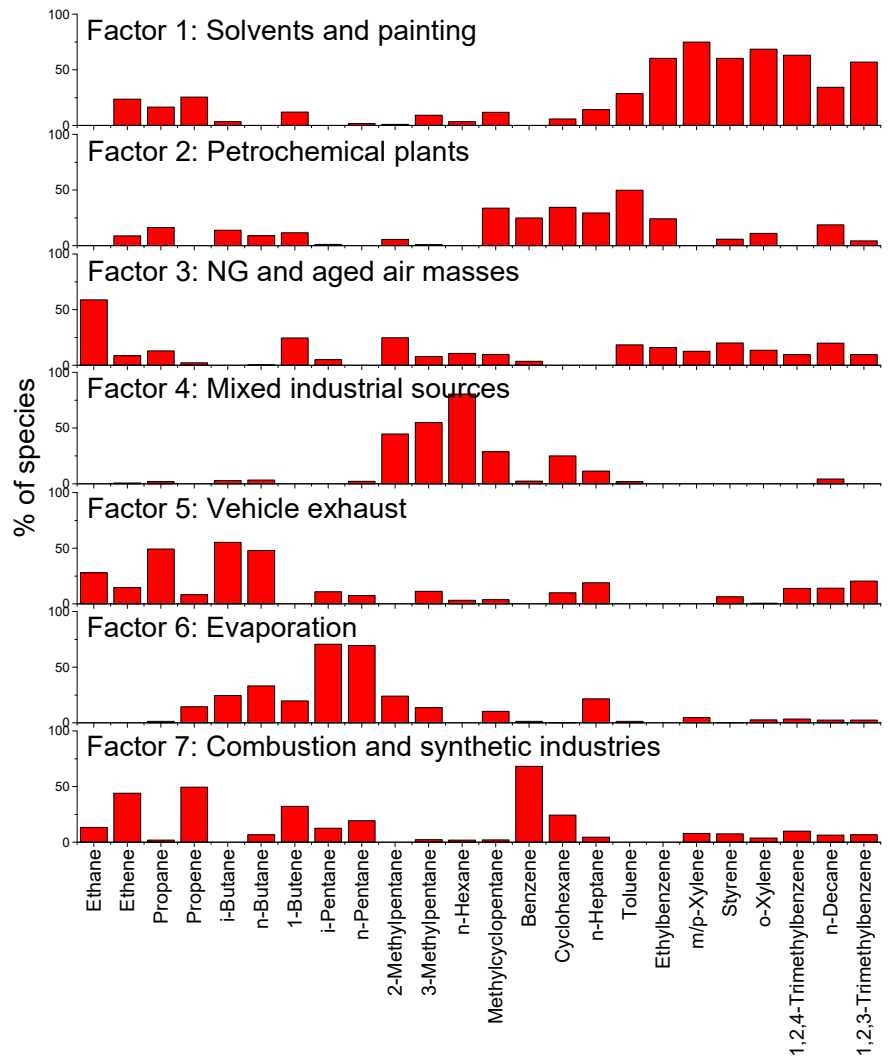

(a)

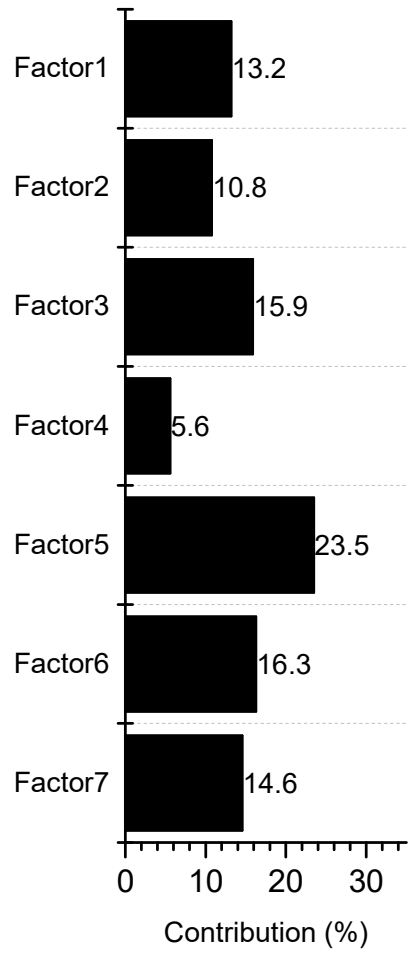

(b)

Fig. 5. (a) The identified sources with VOCs profiles and (b) their contributions to annual VOCs from the PMF model at the NJU site.

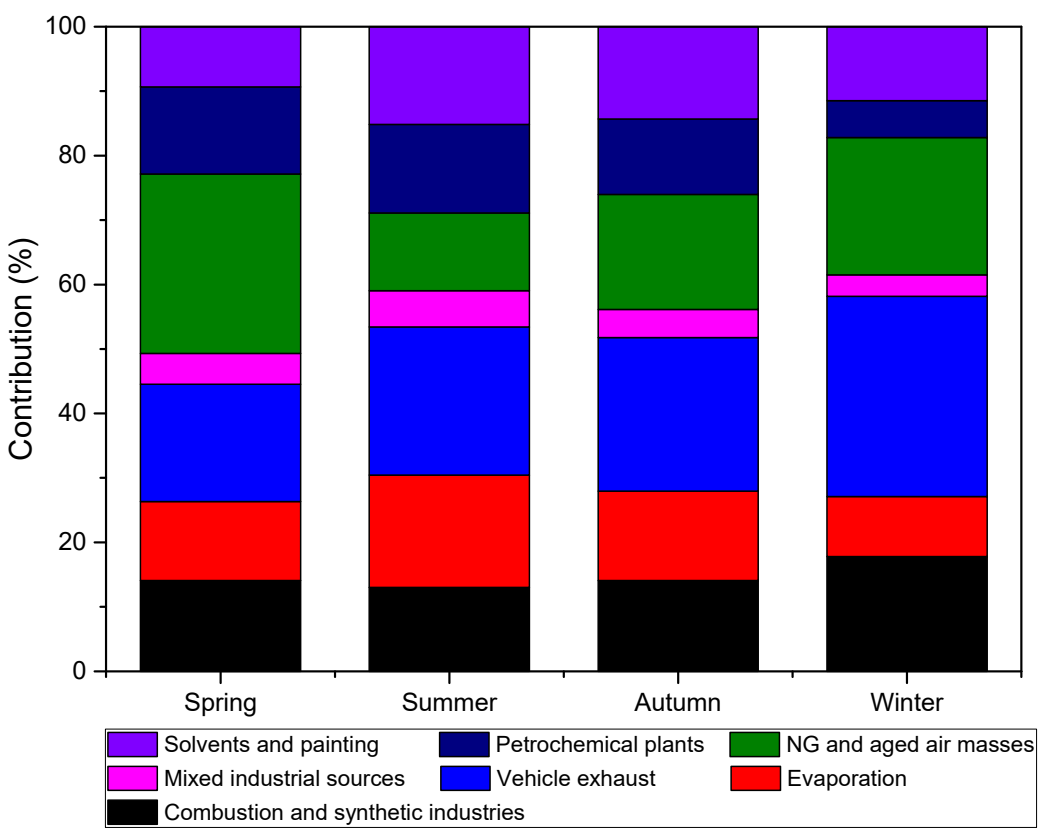

Fig. 6. Variations in the seasonal averaged contributions of the seven modeled VOCs sources (expressed in percent).

$n$-Hexane and its isomers 2-methylpentane and 3methylpentane had high percentage contributions in Factor 4. $n$-Hexane is an ingredient of special glues that are used in the shoe-making and leather industries. It has also been reported that $n$-hexane is used as a cleansing agent for shoes, furniture and textiles (ATSDR, 1999). 2-Methylpentane has been widely used as a nonpolar solvent (Kwon et al., 2007). As shown in Fig. S3(d), the diurnal variation of this factor 
was characterized by a double-wave profile, with an initial increase from 09:00 to 12:00 LT and a second increase between 14:00 and 18:00 LT, consistent with the daily working hours. Therefore, Factor 4 was identified as mixed industrial sources associated with private shops that serve the daily needs of the nearby population.

The species in Factor 5 and Factor 6 appeared to overlap. High loadings of propane, $i$-butane and $n$-butane were found in Factor 5, similar to the source profile of LPG taxis investigated in Hong Kong (Ho et al., 2013). For Factor 6, pentane isomers and butane isomers were weighted relatively more. $\mathrm{C}_{3}-\mathrm{C}_{5}$ alkanes were the main components of LPG, NG and gasoline (McCarthy et al., 2013; Barletta et al., 2005). To further distinguish these two factors, correlation analysis was conducted between factor contribution and relevant vehicle exhaust markers $\left(\mathrm{NO}_{2}\right.$ and ethene; Brown et al., 2007; Bari et al., 2018), as shown in Fig. S4(a)-S4(d). Factor 5 displayed moderate correlations with $\mathrm{NO}_{2}\left(\mathrm{R}^{2}=0.26\right)$ and ethene $\left(\mathrm{R}^{2}=0.39\right)$, while Factor 6 displayed poor correlations with $\mathrm{NO}_{2}\left(\mathrm{R}^{2}=0.04\right)$ and ethene $\left(\mathrm{R}^{2}=0.12\right)$. On the other hand, the highest contribution of Factor 5 was observed in winter $(31 \%)$, whereas the highest contribution of Factor 6 was observed in summer $(17 \%)$. These seasonal variations were consistent with the emission strength of vehicle exhaust and fuel evaporation, respectively. Therefore, Factor 5 could be identified as vehicle exhaust and Factor 6 could be identified as fuel evaporation.

Factor 7 was dominated by ethene, propene and benzene, and was moderately influenced by $\mathrm{C} 4$ alkene. These species are the key markers of combustion. Ethene and propene are also used as feedstock in synthetic industries. As shown in Fig. S4(e), Factor 7 displayed moderate correlations with $\mathrm{CO}\left(\mathrm{R}^{2}=0.30\right)$, a tracer for combustion sources (Borbon et al., 2013; Barletta et al., 2016). Therefore, Factor 7 was supposed to be a mixed source of combustion and synthetics. As shown in Fig. S3(g), the contributions of Factor 7 were clearly elevated during the day (from 08:00 to 17:00); thus, this factor was attributed to industrial sources related to combustion and chemical synthesis engineering.

In summary, traffic emissions (i.e., vehicle exhaust), and $\mathrm{NG}$ and aged air masses contributed $23.5 \%$ and $15.9 \%$ of VOCs in suburban areas. The emissions from solvents and painting $(13.2 \%)$, petrochemical plants $(10.8 \%)$, mixed industrial sources (5.6\%), evaporation (16.3\%) and combustion and synthetic industries (14.6\%) were grouped as "industrial emissions," and they were estimated to collectively contribute $60.5 \%$ to the ambient VOCs. However, according to a local emission inventory by Zhao et al. (2017), the main contributor of anthropogenic VOCs in Nanjing was industrial emissions $(81.8 \%)$, including industrial processes $(49.9 \%)$ and solvent usage $(30.9 \%)$, which were significantly larger than those from traffic emissions (9.7\%). A larger contribution of traffic emissions from the receptor model has often been found in previous studies (Yuan et al., 2013; Sarkar et al., 2017; Song et al., 2019). For example, in a study conducted in Seoul (Song et al., 2019), the mean contributions of traffic emissions were $44 \%$ as determined by PMF and $14 \%$ as determined by the national emission inventory. The PMF factors probably represented groups of sources rather than specific emission sources. In this study, for example, species in Factor 5 (vehicle exhaust) might also be influenced by the petrochemical industry. Furthermore, the measured VOCs ratios did not exactly represent the emission ratios due to chemical reactions in the atmosphere. The source apportionment result might overestimate the contribution from traffic since unreactive species, such as $\mathrm{C}_{2}-\mathrm{C}_{5}$ alkanes, are more abundant in the emissions. In contrast, the contribution of solvents and painting sources might be underestimated, as they emitted species with relatively short atmospheric lifetimes (e.g., toluene, $m, p$-xylene, and $o$-xylene). The uncertainties in the emission inventory could also partly explain the discrepancies. For example, the vehicle population in Nanjing increased by 16\% from 2014 to 2016 (Bureau of Statistics of Nanjing, 2015, 2017), and elevated emissions of transportation could be expected in recent years.

Nonetheless, the contribution of traffic emissions to the ambient VOCs level in this study was comparable to those estimated for other selected Chinese cities by receptor models. The contribution at NJU, for example, was slightly smaller than the reported result for an urban site in Wuhan (28\%; Lyu et al., 2016) and much smaller than the reported results in Beijing (44\%; Gao et al., 2018) and Hong Kong (48\%; Guo et al., 2011). The discrepancies between cities could be attributed to the different patterns of economic development and the different degrees of progress of emission control for vehicles.

The CWT provided insights into the potential geographic origins of VOCs sources, as shown in Fig. 7. The highest areas of pollution were found to the northwest of NJU, where industrial plants are densely located. The result thus suggested that the VOCs levels at NJU were strongly influenced by local industrial sources. Furthermore, the CWT results revealed that air masses from the northeastern YRD made a large contribution. As mentioned above, surface wind in Nanjing originated mostly from the northeast in winter and from the east and southeast in summer (Ding et al., 2013); thus, surface winds brought polluted air from the YRD and influenced the air quality downwind of Nanjing.

\section{Source Contributions for Clear and Pollution Days}

Based on high-temporal resolution datasets, the source apportionment also provided a unique opportunity to explore the possible variation in source contributions to the inferior air quality during pollution events. The information about the $\mathrm{O}_{3}$ and $\mathrm{PM}_{2.5}$ mass concentrations at the XL site was used to define the pollution events according to the NAAQS-CN. Here, we defined $\mathrm{O}_{3}$ pollution days as the days with 1 -h average $\mathrm{O}_{3}$ mass concentrations exceeding the Class II NAAQS $\left(200 \mu \mathrm{g} \mathrm{m}^{-3}\right)$ for 4 collective hours. The days with daily average $\mathrm{PM}_{2.5}$ mass concentrations exceeding the Class II NAAQS $\left(75 \mu \mathrm{g} \mathrm{m}^{-3}\right)$ were defined as $\mathrm{PM}_{2.5}$ pollution days. The days with an air quality index (AQI) lower than 50 were defined as clear days. The calculation of the AQI is provided by the China National Environmental Monitoring Center (http://www.cnemc.cn/) and is introduced briefly in Section S3.

The selected dates and related air quality data are shown in Fig. S5. There were 19 days of $\mathrm{O}_{3}$ pollution, and most of 


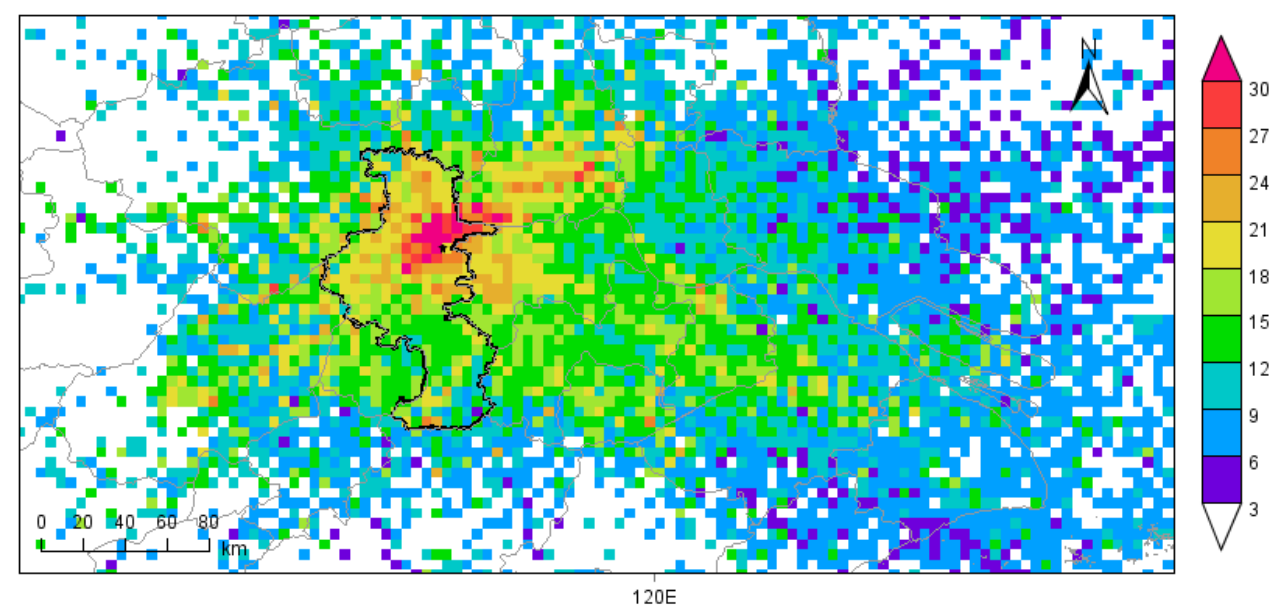

Fig. 7. Geographic origins of the VOCs sources (shaded with colors) identified by concentration weighted trajectory analysis at the NJU site. The black star represents the sampling site.

these days were during warm seasons (May and JulySeptember). $\mathrm{O}_{3}$ pollution in suburban areas occurred early in May, which is possibly attributed to the large amount of precursor emissions from broader regions in the YRD. Xie et al. (2016) indicated that the peak $\mathrm{O}_{3}$ in spring could be first attributed to regional contributions and then to local contributions, whereas an opposite trend was observed in summer. In total, $31 \mathrm{PM}_{2.5}$ pollution days were observed, and most of these days were in winter and early spring because of the frequent unfavorable conditions of atmospheric diffusion. 17 clear days were observed.

The source contributions to ambient VOCs on clear and pollution days are summarized in Table S3, and Fig. 8 illustrates the absolute contribution ratios in different kinds of days (a) and the relative changes in pollution days compared to clear days (b). During the $\mathrm{PM}_{2.5}$ pollution days, the contributions of solvents and painting, petrochemical plants, NG and aged air masses, vehicle exhaust, and combustion and synthetic industries were elevated by $17.9 \%, 16.8 \%$,

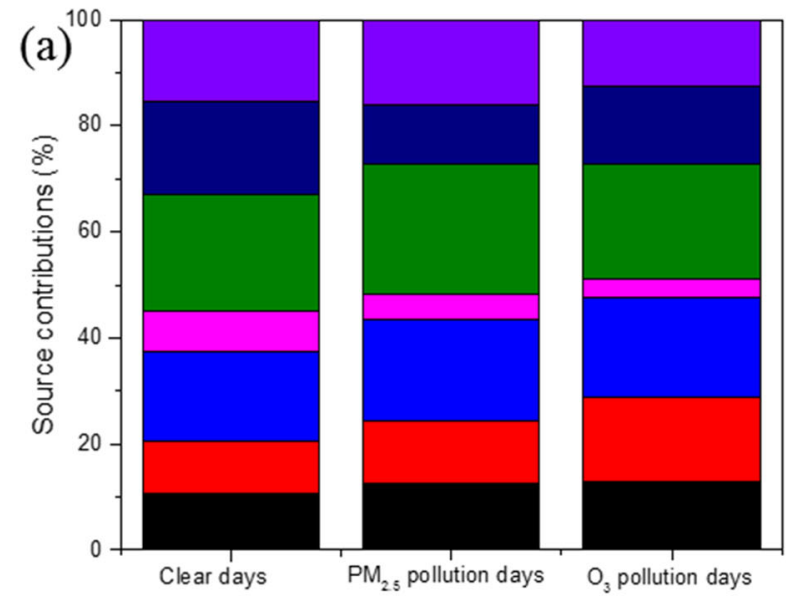

$14.4 \%, 12.3 \%$, and $4.5 \%$, respectively. Accordingly, the contributions of mixed industrial sources and evaporation were reduced by $36.8 \%$ and $36.7 \%$. Aromatic hydrocarbons emitted from solvents and painting and from petrochemical plants had relatively high SOA formation potential. Therefore, the contributions of these sources were observed to increase when $\mathrm{PM}_{2.5}$ levels increased. Furthermore, $\mathrm{PM}_{2.5}$ pollution episodes often occurred under the unfavorable condition of atmospheric diffusion that increased the residence time of air and thus, the contributions of aged air masses were enhanced. Unlike $\mathrm{PM}_{2.5}$ pollution events, the contributions of vehicle exhaust and of combustion and synthetic industry decreased by $1.4 \%$ and $19.5 \%$, respectively, during $\mathrm{O}_{3}$ pollution episodes, along with a dramatic increase in the contributions of petrochemical plants (56.4\%) and solvents and painting $(22.6 \%)$. Except for the high $\mathrm{O}_{3}$ formation potential of species from petrochemical plants, these sources contributed more VOCs in the spring-summer (Fig. 6) because of higher temperatures, therefore leading to

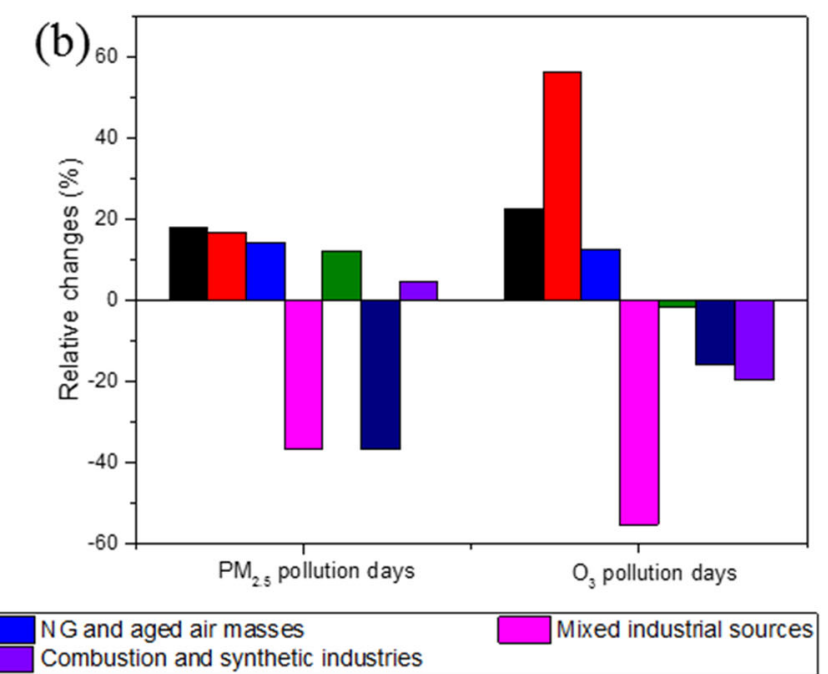

Fig. 8. (a) Source contributions for pollution and clear days and (b) relative changes in the source categories on pollution days compared to those on clear days at the NJU site. 
a rise of $\mathrm{O}_{3}$ levels. The larger contribution of aged air masses during $\mathrm{O}_{3}$ pollution days indicated the importance of regional transport in suburban areas. The results of the contributions of VOCs sources on pollution days suggested that reducing industry-related (especially petrochemical industry and solvents and painting) emissions is an effective way to improve air quality. The regional transport of aged air masses should also be taken into account in order to reduce VOCs levels in suburban areas.

\section{CONCLUSIONS}

The concentrations of 55 VOCs species were measured based on hourly observations at a suburban site from March 2016 to February 2017 in Nanjing, China. It was found that the VOCs were dominated by alkanes, followed by aromatics and alkenes, and their concentrations and compositions differed from those in industrial areas in Nanjing. Furthermore, autumn and winter exhibited higher concentrations than spring and summer for most of the species. The ratios for $i$-pentane/ $n$-pentane and $m, p$-xylene/ethylbenzene indicated that the atmospheric VOCs in suburban Nanjing were influenced by fuel evaporation and long-distance transport. Source apportionment, as determined by PMF, revealed that large local emissions, particularly vehicle exhaust and evaporation, were key factors in the high levels of ambient VOCs. Additionally, the contribution from traffic exceeded that in the local emission inventory due to uncertainties in both methodologies. The CWT results demonstrated that the VOCs in this study mainly originated in the industrial areas of northeastern Nanjing and the upwind YRD. In light of the various contributions to VOCs during pollution episodes, reducing industrial emissions, especially from petrochemical industries, and solvents and painting, may be an effective way to improve air quality. Moreover, the significant contribution of regional aged air masses in suburban areas emphasizes the importance of jointly controlling VOCs on a broader regional scale.

\section{ACKNOWLEDGEMENTS}

This work received support from the National Key Research and Development Program of China (2017YFC0210106) and the Natural Science Foundation of China (91644220 and 41922052). We also thank the Qingyue Open Environmental Data Center (https://data.epmap.org) for its support on air quality data.

\section{SUPPLEMENTARY MATERIAL}

Supplementary data associated with this article can be found in the online version at http://www.aaqr.org.

\section{REFERENCES}

An, J.L., Zhu, B., Wang, H.L., Li, Y.Y., Lin, X. and Yang, H. (2014). Characteristics and source apportionment of VOCs measured in an industrial area of Nanjing, Yangtze River Delta, China. Atmos. Environ. 97: 206-214.
Atkinson, R. (1986). Kinetics and mechanisms of the gasphase reactions of the hydroxyl radical with organic compounds under atmospheric conditions. Chem. Rev. 86: 69-201.

ATSDR (Agency for Toxic Substances and Disease Registry) (1999). Toxicological profile for n-hexane. U.S. Department of Health and Human Services, Public Health Service, Atlanta, GA.

Bari, M.A. and Kindzierski, W.B. (2018). Ambient volatile organic compounds (VOCs) in communities of the Athabasca oil sands region: Sources and screening health risk assessment. Environ. Pollut. 235: 602-614.

Barletta, B., Meinardi, S., Rowland, F.S., Chan, C.Y., Wang, X.M., Zou, S.C., Chan, L.Y. and Blake, D.R. (2005). Volatile organic compounds in 43 Chinese cities. Atmos. Environ. 39: 5979-5990.

Barletta, B., Simpson, I.J., Blake, N.J., Meinardi, S., Emmons, L.K., Aburizaiza, O.S., Siddique, A., Zeb, J., Yu, L.E., Khwaja, H.A., Farrukh, M.A. and Blake, D.R. (2016). Characterization of carbon monoxide, methane and nonmethane hydrocarbons in emerging cities of Saudi Arabia and Pakistan and in Singapore. J. Atmos. Chem. 74: 87-113.

Baudic, A., Gros, V., Sauvage, S., Locoge, N., Sanchez, O., Sarda-Estève, R., Kalogridis, C., Petit, J.E., Bonnaire, N., Baisnée, D., Favez, O., Albinet, A., Sciare, J. and Bonsang, B. (2016). Seasonal variability and source apportionment of volatile organic compounds (VOCs) in the Paris megacity (France). Atmos. Chem. Phys. 16: 11961-11989.

Bureau of Statistics of Nanjing (2015). Nanjing Statistical Yearbook. China Statistics Press, Beijing.

Bureau of Statistics of Nanjing (2017). Nanjing Statistical Yearbook. China Statistics Press, Beijing.

Buzcu, B. and Fraser, M.P. (2006). Source identification and apportionment of volatile organic compounds in Houston, TX. Atmos. Environ. 40: 2385-2400.

Cai, C.J., Geng, F.H., Tie, X.X., Yu, Q. and An, J.L. (2010). Characteristics and source apportionment of VOC measured in Shanghai, China. Atmos. Environ. 44: 5005-5014.

Chen, D., Cui, H.F., Zhao, Y., Yin, L.N., Lu, Y. and Wang, Q.G. (2017). A two-year study of carbonaceous aerosols in ambient $\mathrm{PM}_{2.5}$ at a regional background site for western Yangtze River Delta, China. Atmos. Res. 183: 351-361.

Chen, D., Zhao, Y., Lyu, R.T., Wu, R.R., Dai, L., Zhao, Y., Chen, F., Zhang, J., Yu, H. and Guan, M. (2019). Seasonal and spatial variations of optical properties of light absorbing carbon and its influencing factors in a typical polluted city in Yangtze River Delta, China. Atmos. Environ. 199: 45-54.

Ding, A.J., Fu, C.B., Yang, X.Q., Sun, J.N., Zheng, L.F., Xie, Y.N., Herrmann, E., Nie, W., Petäjä, T., Kerminen, V.M. and Kulmala, M. (2013). Ozone and fine particle in the western Yangtze River Delta: An overview of $1 \mathrm{yr}$ data at the SORPES station. Atmos. Chem. Phys. 13: 58135830 .

Gao, J., Zhang, J., Li, H., Li, L., Xu, L.H., Zhang, Y.J., Wang, Z.S., Wang, X.Z., Zhang, W.Q., Chen, Y.Z., Cheng, X., Zhang, H., Peng, L., Chai, F.H. and Wei, Y.J. 
(2018). Comparative study of volatile organic compounds in ambient air using observed mixing ratios and initial mixing ratios taking chemical loss into account - A case study in a typical urban area in Beijing. Sci. Total Environ. 628-629: 791-804.

Garzón, J.P., Huertas, J.I., Magaña, M., Huertas, M.E., Cárdenas, B., Watanabe, T., Maeda, T., Wakamatsu, S. and Blanco, S. (2015). Volatile organic compounds in the atmosphere of Mexico City. Atmos. Environ. 119: 415429.

George, I.J., Hays, M.D., Herrinton, J.S., Preston, W., Snow, R., Faircloth, J., George, B.J., Long, T. and Baldauf, R.W. (2015). Effects of cold temperature and ethanol content on VOC emissions from light-duty gasoline vehicles. Environ. Sci. Technol. 49: 13067-13074.

Gilman, J.B., Lerner, B.M., Kuster, W.C. and De Gouw, J.A. (2013). Source signature of volatile organic compounds from oil and natural gas operations in northeastern Colorado. Environ. Sci. Technol. 47: 1297-1305.

Guenther, A., Karl, T., Harley, P., Wiedinmyer, C., Palmer, P.I. and Geron, C. (2006). Estimates of global terrestrial isoprene emissions using MEGAN (Model of Emissions of Gases and Aerosols from Nature). Atmos. Chem. Phys. 6: 3181-3210.

Guo, H., Cheng, H.R., Ling, Z.H., Louie, P.K. and Ayoko, G.A. (2011). Which emission sources are responsible for the volatile organic compounds in the atmosphere of Pearl River Delta? J. Hazard. Mater. 188: 116-124.

He, J.J., Gong, S.L., Yu, Y., Yu, L.J., Wu, L., Mao, H.J., Song, C.B., Zhao, S.P., Liu, H.L., Li, X.Y. and Li, R.P. (2017). Air pollution characteristics and their relation to meteorological conditions during 2014-2015 in major Chinese cities. Environ. Pollut. 223: 484-496.

Ho, K.F., Ho, S.S.H., Lee, S.C., Louie, P.K.K., Cao, J. and Deng, W. (2013). Volatile organic compounds in roadside environment of Hong Kong. Aerosol Air Qual. Res. 13: 1331-1347.

Hopke, P. (2000). A guide to positive matrix factorization. Paper presented at Workshop on UNMIX and PMF as Applied to $\mathrm{PM}_{2.5}$, U.S. Environmental Protection Agency, Research Triangle Park, N. C.

Hu, B.Y., Xu, H., Deng, J.J., Yi, Z.G., Chen, J.S., Xu L.L., Hong, Z.Y., Chen, X.Q. and Hong, Y.W. (2018). Characteristics and source apportionment of volatile organic compounds for different functional zones in a coastal city of southeast China. Aerosol Air Qual. Res. 18: 2840-2852.

Huang, C., Chen, C.H., Li, L., Cheng, Z., Wang, H.L., Huang, H.Y., Streets, D.G., Wang, Y.J., Zhang, G.F. and Chen, Y.R. (2011). Emission inventory of anthropogenic air pollutants and VOC species in the Yangtze River Delta region, China. Atmos. Chem. Phys. 11: 4105-4120.

Huang, R.J., Zhang, Y., Bozzetti, C., Ho, K.F., Cao, J.J., Han, Y., Daellenbach, K.R., Slowik, J.G., Platt, S.M., Canonaco, F., Zotter, P., Wolf, R., Pieber, S.M., Bruns, E.A., Crippa, M., Ciarelli, G., Piazzalunga, A., Schwikowski, M., Abbaszade, G., Schnelle-Kreis, J., Zimmermann, R., An, Z., Szidat, S., Baltensperger, U., El Haddad, I. and Prevot, A.S. (2014). High secondary aerosol contribution to particulate pollution during haze events in China. Nature. 514: 218-222.

Huang, Y.S. and Hsieh, C.C. (2019). Ambient volatile organic compound presence in the highly urbanized city: Source apportionment and emission position. Atmos. Environ. 206: 45-59.

Hui, L., Liu, X., Tan, Q., Feng, M., An, J., Qu, Y., Zhang, Y. and Jiang, M. (2018). Characteristics, source apportionment and contribution of vocs to ozone formation in wuhan, central China. Atmos. Environ. 192: 55-71.

Jiang, M.Q., Lu, K.D., Su, R., Tan, Z.F., Wang, H.L., Li, L., Fu, Q.Y., Zhai, C.Z., Tan, Q.W., Yue, D.L., Chen, D.H., Wang, Z.S., Xie, S.D., Zeng, L.M. and Zhang, Y.H. (2018). Ozone formation and key VOCs in typical Chinese city clusters. Chin. Sci. Bull. 63: 1130-1141.

Kuntasal, O.O., Kilavuz, S.A., Karman, D., Wang, D. and Tuncel, G. (2013). $\mathrm{C}_{5}-\mathrm{C}_{12}$ volatile organic compounds at roadside, residential, and background locations in Ankara, Turkey: Temporal and spatial variations and sources. $J$. Air Waste Manage. Assoc. 63: 1148-1162.

Kwon, K.D., Jo, W.K., Lim, H.J. and Jeong, W.S. (2007). Characterization of emissions composition for selected household products available in Korea. J. Hazard. Mater. 148: 192-198.

Latif, M.T., Huey, L.S. and Juneng, L. (2012). Variations of surface ozone concentration across the Klang Valley, Malaysia. Atmos. Environ. 61: 434-445.

Leuchner, M. and Rappenglück, B. (2010). VOC sourcereceptor relationships in Houston during TexAQS-II. Atmos. Environ. 44: 4056-4067.

Li, H.M., Wang, Q.G., Yang, M., Li, F.Y., Wang, J.H., Sun, Y.X., Wang, C., Wu, H.F. and Qian, X. (2016). Chemical characterization and source apportionment of $\mathrm{PM}_{2.5}$ aerosols in a megacity of Southeast China. Atmos. Res. 181: 288-299.

Li, J., Xie, S.D., Zeng, L.M., Li, L.Y., Li, Y.Q. and Wu, R.R. (2015). Characterization of ambient volatile organic compounds and their sources in Beijing, before, during, and after Asia-Pacific Economic Cooperation China 2014. Atmos. Chem. Phys. 15: 7945-7959.

Lyu, X.P., Liu, M., Guo, H., Ling, Z.H., Wang, Y., Louie, P.K.K. and Luk, C.W.Y. (2016). Spatiotemporal variation of ozone precursors and ozone formation in Hong Kong: Grid field measurement and modelling study. Sci. Total Environ. 569-570: 1341-1349.

Mccarthy, M.C., Aklilu, Y.A., Brown, S.G. and Lyder, D.A. (2013). Source apportionment of volatile organic compounds measured in Edmonton, Alberta. Atmos. Environ. 81: 504-516.

Mcgaughey, G.R., Desai, N.R., Allen, D.T., Seila, R.L., Lonneman, W.A., Fraser, M.P., Harley, R.A., Pollack, A.K., Ivy, J.M. and Price, J.H. (2004). Analysis of motor vehicle emissions in a Houston tunnel during the Texas Air Quality Study 2000. Atmos. Environ. 38: 3363-3372.

Ministry of Environmental Protection of China (MEP) (2012). National Ambient Air Quality Standards (NAAQS$C N)$. China Environmental Science Press, Beijing, China. Ministry of Environmental Protection of the People's Republic (MEP) (2018). China statistical yearbook on 
environment. http://www.mee.gov.cn/home/jrtt_1/20190 5/t20190529 704841.shtml.

Mo, Z.W., Shao, M., Lu, S.H., Niu, H., Zhou, M.Y. and Sun, J. (2017). Characterization of non-methane hydrocarbons and their sources in an industrialized coastal city, Yangtze River Delta, China. Sci. Total Environ. 593-594: 641653.

Mo, Z.W., Shao, M., Liu, Y., Xiang, Y., Wang, M., Lu, S.H., Ou, J.M., Zheng, J.Y., Li, M., Zhang, Q., Wang, X.M. and Zhong, L.J. (2018). Species-specified VOC emissions derived from a gridded study in the Pearl River Delta, China. Sci. Rep. 8: 2963.

Mochizuki, T., Tani, A., Takahashi, Y., Saigusa, N. and Ueyama, M. (2014). Long-term measurement of terpenoid flux above a Larix kaempferi forest using a relaxed eddy accumulation method. Atmos. Environ. 83: 53-61.

Monod, A., Sive, B.C., Avino, P., Chen, T., Blake, D.R. and Sherwood R. (2001). Monoaromatic compounds in ambient air of various cities: A focus on correlations between the xylenes and ethlbenzene. Atmos. Environ. 35: 135-149.

Ou, J.M., Guo, H., Zheng, J.Y., Cheung, K., Louie, P.K.K., Ling, Z.H. and Wang, D.W. (2015). Concentrations and sources of non-methane hydrocarbons (NMHCs) from 2005 to 2013 in Hong Kong: A multi-year real-time data analysis. Atmos. Environ. 103: 196-206.

Ou, J.M., Zheng, J.Y., Yuan, Z.B., Guan, D.B., Huang, Z.J., Yu, F., Shao, M. and Louie, P.K.K. (2018). Reconciling discrepancies in the source characterization of VOCs between emission inventories and receptor modeling. Sci. Total Environ. 628-629: 697-706.

Paatero, P. (1997). Least squares formulation of robust nonnegative factor analysis. Chemom. Intell. Lab. Syst. 37: $23-35$.

Paatero, P. and Tapper, U. (1994). Positive matrix factorization: A non-negative factor model with optimal utilization of error estimates of data values. Environmetrics 5: 111-126.

Polissar, A.V., Hopke, P.K. and Paatero, P. (1998). Atmospheric aerosol over Alaska - 2. Elemental composition and sources. J. Geophys. Res. 103: 19045-19057.

Reff, A., Eberly, S.I. and Bhave, P.V. (2007). Receptor modeling of ambient particulate matter data using positive matrix factorization: Review of existing methods. J. Air Waste Manage. Assoc. 57: 146-154.

Sarkar, C., Sinha, V., Sinha, B., Panday, A.K., Rupakheti, M. and Lawrence, M.G. (2017). Source apportionment of NMVOCs in the Kathmandu Valley during the SusKatABC international field campaign using positive matrix factorization. Atmos. Chem. Phys. 17: 8129-8156.

Song, S.K., Shon, Z.H., Kang, Y.H., Kim, K.H., Han, S.B., Kang, M., Bang, J.H. and Oh, I. (2019). Source apportionment of VOCs and their impact on air quality and health in the megacity of Seoul. Environ. Pollut. 247: 763-774.

Sun, J., Wu, F.K., Hu, B., Tang, G.Q., Zhang, J.K. and Wang, Y.S. (2016). VOC characteristics, emissions and contributions to SOA formation during hazy episodes. Atmos. Environ. 141: 560-570.
Tiwari, V., Hanai, Y. and Masunaga, S. (2010). Ambient levels of volatile organic compounds in the vicinity of petrochemical industrial area of Yokohama, Japan. Air Qual. Atmos. Health 3: 65-75.

U.S. EPA (U.S. Environmental Protection Agency) (2014). EPA Positive Matrix Factorization (PMF) 5.0, fundamentals and user guide. http://www.epa.gov/heasd/ research/pmf.html.

Wang, B., Shao, M., Lu, S.H., Yuan, B., Zhao, Y., Wang, M., Zhang, S.Q. and Wu, D. (2010). Variation of ambient non-methane hydrocarbons in Beijing city in summer 2008. Atmos. Chem. Phys. 10: 5911-5923.

Wang, H.L., Qiao, Y.Z., Chen, C.H., Lu, J., Dai, H.X, Qiao, L.P., Lou, S.R., Huang, C., Li, L., Jing, S.G. and Wu, J.P. (2014). Source profiles and chemical reactivity of volatile organic compounds from solvent use in Shanghai, China. Aerosol Air Qual. Res. 14: 301-310.

Wang, M., Shao, M., Chen, W., Lu, S., Liu, Y., Yuan, B., Zhang, Q., Zhang, Q., Chang, C.C., Wang, B., Zeng, L., $\mathrm{Hu}, \mathrm{M}$., Yang, Y. and Li, Y. (2015b). Trends of nonmethane hydrocarbons (NMHC) emissions in Beijing during 2002-2013. Atmos. Chem. Phys. 15: 1489-1502.

Wang, Y.Q., Zhang, X.Y. and Draxler, R.R. (2009). TrajStat: GIS-based software that uses various trajectory statistical analysis methods to identify potential sources from long-term air pollution measurement data. Environ. Modell. Software 24: 938-939.

Watson, J.G., Chow, J.C. and Fujita, E.M. (2001). Review of volatile organic compound source apportionment by chemical mass balance. Atmos. Environ. 35: 1567-1584.

WHO (2003). Health aspects of air pollution with particulate matter, ozone and nitrogen dioxide: Report on a WHO working group, Bonn, Germany 13-15 January 2003, World Health Organization.

Wu, R.R., Li, J., Hao, Y.F., Li, Y.Q., Zeng, L.M. and Xie, S.D. (2016). Evolution process and sources of ambient volatile organic compounds during a severe haze event in Beijing, China. Sci. Total Environ. 560-561: 62-72.

Wu, R.R. and Xie, S.D. (2017). Spatial distribution of ozone formation in China Derived from emissions of speciated volatile organic compounds. Environ. Sci. Technol. 51: 2574-2583.

Xia, L., Cai, C.J., Zhu, B., An, J.L., Li, Y.Y. and Li, Y. (2014). Source apportionment of VOCs in a suburb of Nanjing, China, in autumn and winter. J. Atmos. Chem. 71: 175-193.

Xiao, Y.P., Logan, J.A., Jacob, D.J., Hudman, R.C., Yantosca, R. and Blake, D.R. (2008). Global budget of ethane and regional constraints on U.S. sources, $J$. Geophys. Res. 113: D21306.

Xie, M., Zhu, K.G., Wang, T.J., Chen, P.L., Han, Y., Li, S., Zhuang, B.L. and Shu, L. (2016). Temporal characterization and regional contribution to $\mathrm{O}_{3}$ and $\mathrm{NO}_{x}$ at an urban and a suburban site in Nanjing, China. Sci. Total Environ. 551-552: 533-545.

Xu, W.Y., Xu, X.B., Lin, M.Y., Lin, W.L., Tarasick, D., Tang, J., Ma, J.Z. and Zheng, X.D. (2018). Long-term trends of surface ozone and its influencing factors at the Mt Waliguan GAW station, China - Part 2: The roles of 
anthropogenic emissions and climate variability. Atmos. Chem. Phys. 18: 773-798.

Yan, Y.L., Peng, L., Li, R.M., Li, Y.H., Li, L.J. and Bai, H.L. (2017). Concentration, ozone formation potential and source analysis of volatile organic compounds (VOCs) in a thermal power station centralized area: A study in Shuozhou, China. Environ Pollut. 223: 295-304.

Yuan, B., Shao, M., Gouw, D.J., Parrish, D.D., Lu, S.H., Wang, M., Zeng, L.M., Zhang, Q., Song, Y., Zhang, J.B. and $\mathrm{Hu}, \mathrm{M}$. (2012). Volatile organic compounds (VOCs) in urban air: How chemistry affects the interpretation of positive matrix factorization (PMF) analysis. J. Geophys. Res. 117: D24302.

Yuan, Z.B., Zhong, L.J., Lau, A.K.H., Yu, J.Z. and Louie, P.K.K. (2013). Volatile organic compounds in the Pearl River Delta: Identification of source regions and recommendations for emission-oriented monitoring strategies. Atmos. Environ. 76: 162-172.

Yurdakul, S., Civan, M., Kuntasal, O., Dogan, G., Pekey, H. and Tuncel, G. (2018). Temporal variations of VOC concentrations in Bursa atmosphere. Atmos. Pollut. Res. 9: 189-206.

Zhang, Y.L., Wang, X.M., Zhang, Z., Lu, S.J, Huang, Z.H. and Li, L.F. (2015). Sources of $\mathrm{C}_{2}-\mathrm{C}_{4}$ alkenes, the most important ozone nonmethane hydrocarbon precursors in the Pearl River Delta region. Sci. Total Environ. 502: 236-245.

Zhao, X.F., Zhao, Y., Chen, D., Li, C.Y. and Zhang, J. (2019). Top-down estimate of black carbon emissions for city clusters using ground observations: a case study in southern Jiangsu, China. Atmos. Chem. Phys. 19: 20952113.

Zhao, Y., Mao, P., Zhou, Y.D., Yang, Y., Zhang, J., Wang, S.K., Dong, Y.P., Xie, F.J., Yu, Y.Y. and Li, W.Q. (2017). Improved provincial emission inventory and speciation profiles of anthropogenic non-methane volatile organic compounds: A case study for Jiangsu, China. Atmos. Chem. Phys. 17: 7733-7756.

Zheng, H., Kong, S.F., Xing, X.L., Mao, Y., Hu, T.P., Ding, Y., Li, G., Liu, D.T., Li, S.L. and Qi, S.H. (2018). Monitoring of volatile organic compounds (VOCs) from an oil and gas station in northwest China for 1 year. Atmos. Chem. Phys. 18: 4567-4595.

Zhu, H.L., Wang, H.L., Jing, S.G., Wang, Y.F., Cheng, T.T., Tao, S.K., Lou, S.R., Qiao, L.P., Li, L. and Chen, J.M. (2018). Characteristics and sources of atmospheric volatile organic compounds (VOCs) along the mid-lower Yangtze River in China. Atmos. Environ. 190: 232-240.

Zou, Y., Deng, X.J., Zhu, D., Gong, D.C., Wang, H., Li, F., Tan, H.B., Deng, T., Mai, B.R., Liu, X.T. and Wang, B.G. (2015). Characteristics of 1 year of observational data of VOCs, $\mathrm{NO}_{x}$ and $\mathrm{O}_{3}$ at a suburban site in Guangzhou, China. Atmos. Chem. Phys. 15: 6625-6636.

Received for review, October 20, 2019 Revised, January 3, 2020 Accepted, January 10, 2020 